\title{
Initial limnological observations at five small lakes in southern Pacific Costa Rica
}

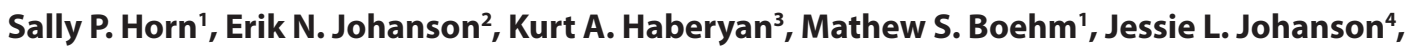 \\ Maureen Sánchez P. ${ }^{5}$ \& Mario Hernández V. ${ }^{6}$
}

1. Department of Geography, University of Tennessee, Knoxville, TN 37996-0925, USA; shorn@utk.edu; mboehm2@vols.utk.edu

2. Department of Geosciences, Florida Atlantic University, Boca Raton, FL 33431, USA; ejohanson@fau.edu

3. Department of Natural Sciences, Northwest Missouri State University, Maryville, MO 64468-6001, USA; khaber@nwmissouri.edu

4. Department of Anthropology, University of Tennessee, Knoxville, TN 37996-0720, USA; jlj@vols.utk.edu

5. School of Anthropology, University of Costa Rica, Ciudad Universitaria, Costa Rica; maureen.crisur@gmail.com

6. Consultant in archaeology and geography, San José, Costa Rica; marhv@yahoo.com

Received 27-VII-2017 • Corrected 06-IX-2017 • Accepted 21-IX-2017

\begin{abstract}
Costa Rica has hundreds of lakes, many of which have never been described or sampled by limnologists. Here we summarize initial observations of five small (0.2-1.7ha) lakes located at low elevation (365-490m) in the cantón of Buenos Aries. We collected basic limnological data and samples during visits in 2013 and 2014, and compiled environmental and archaeological data for their surroundings as a contribution to the documentation of lake diversity in Costa Rica, and to support parallel investigations of indicators of environmental history preserved in the sediments of the lakes. Lagunas Carse, Los Mangos, Danta, and Ojo de Agua all appear to owe their origin to landslide events, while Laguna Junquillo is an artificial impoundment. Radiocarbon dates on plant macrofossils near the bases of sediment cores from three of the natural lakes provide minimum ages for lake formation; results indicate that Laguna Los Mangos formed over 4100 years ago, while Laguna Danta formed prior to 1320 CE and Laguna Carse formed ca. $1550 \mathrm{CE}$, near the time of the Spanish Conquest. More than two dozen archaeological sites are located within $1-3 \mathrm{Km}$ of the natural lakes, documenting pre-Columbian human occupation and likely use of lake resources. Lake water temperatures and water chemistry were in keeping with observations at lakes throughout Costa Rica. All five lakes are probably polymictic lakes that turn over frequently; none evinced stratification. The surface lake sediments showed similar organic matter content $(22,1-28,8 \%)$, with values falling near the middle of the range of lakes previously sampled in Costa Rica. Phytoplankton samples included taxa previously reported from small lowland lakes, but differed between lakes and included dominant taxa that were subdominant or uncommon at other lakes surveyed. Our investigation adds to knowledge of lake characteristics and diversity in Costa Rica, and provides benchmarks for assessing future changes in these lakes and their watersheds resulting from human activity, natural disturbances, and regional and global climate change.
\end{abstract}

Key words: lakes, limnology, phytoplankton, polymictic, landslides, environmental history, sediments
RESUMEN: Observaciones limnológicas iniciales en cinco pequeños lagos del Pacífico Sur, Costa Rica. Costa Rica tiene cientos de lagos, muchos de los cuales nunca han sido descritos o muestreados por los limnólogos. Aquí se resumen las observaciones iniciales de cinco lagos pequeños (0,2-1,7ha) situados en baja elevación (365-490m) en el cantón de Buenos Aires. Recolectamos datos limnológicos básicos y muestras durante visitas en el 2013 y 2014 y se recopilaron datos ambientales y arqueológicos para el entorno, como contribución a la documentación de la diversidad de los lagos en Costa Rica y para apoyar investigaciones paralelas de los indicadores de historia ambiental en los sedimentos de los lagos. Lagunas Carse, Los Mangos, Danta y Ojo de Agua parecen tener su origen en eventos de deslizamiento, mientras que Laguna Junquillo es un embalse artificial. Las fechas de radiocarbono en los macrofósiles de las plantas cerca de las bases de los núcleos de sedimentos de tres de los lagos naturales proporcionan edades mínimas para la formación del lago; los resultados indican que la Laguna Los Mangos se formó hace más de 4100 años, mientras que la Laguna Danta se formó antes de $1320 \mathrm{dC}$ y Laguna Carse formó ca. $1550 \mathrm{dC}$, cerca de la época de la conquista española. Más de dos docenas de sitios arqueológicos están ubicados a 1-3Km de los lagos naturales, documentando la ocupación humana precolombina y el uso probable de los recursos lacustres. La temperatura del agua en los lagos y la química del agua concuerdan con las observaciones en los lagos de toda Costa Rica. Los cinco lagos son probablemente lagos polimíticos que revuelven con frecuencia; ninguno evidenció estratificación. Los sedimentos superficiales de los lagos mostraron un contenido similar de materia orgánica (22,1-28,8\%), con valores cercanos a la mitad del rango de lagos previamente muestreados en Costa Rica. Las muestras de fitoplancton incluyeron taxones previamente reportados de lagos pequeños de tierras bajas, pero diferían entre los lagos e incluían taxones dominantes que eran subdominantes o poco comunes en otros lagos estudiados. Nuestra investigación se suma al conocimiento de las características y diversidad de los lagos en Costa Rica y proporciona puntos de referencia para evaluar los cambios futuros en estos lagos y sus cuencas derivadas de la actividad humana, las perturbaciones naturales y el cambio climático regional y global.

Palabras clave: lagos, limnología, fitoplancton, polimíctico, deslizamientos, historia ambiental, sedimentos 
Costa Rica has hundreds of lakes, ranging in size from less than 1 ha to over 8000 ha, and occupying diverse climate zones from sea level on both coasts to the country's highest peaks (Horn \& Haberyan, 1993, 2016; Haberyan, Horn \& Umaña, 2003; Umaña, Haberyan, \& Horn, 1999). These lakes have been created by volcanism, stream dynamics, faulting, landslides, glaciation, and human actions. Costa Rican and foreign researchers have been investigating lakes in Costa Rica since the 1960s, with studies focusing on the physical and chemical properties of lakes, lake biology, and evidence of lake and ecosystem history preserved in sediments (Umaña et al., 1999; Horn \& Haberyan, 2016). Government agencies have carried out lake inventories in collaboration with international partners (Córdoba Muñoz, Romero Araya \& Windevoxhel Lora, 1998; PREPAC, 2005) that have included some field visits. However, the limnology of many lakes remains to be characterized.

Here we describe the limnology and setting of five lakes in the southern Pacific region of Costa Rica. We collected basic limnological data from these lakes and compiled environmental and archaeological data for their surroundings as a contribution to the documentation of lake diversity in Costa Rica, and to support our investigations of biological and geochemical indicators of environmental history preserved in the sediments of these lakes.

\section{MATERIAL AND METHODS}

The five lakes we investigated are located in the cantón of Buenos Aires in the Valle del General in southern Pacific Costa Rica (Fig. 1). Four lakes are located south of the Río General, three (Laguna Los Mangos, Laguna Danta, and Laguna Ojo de Agua) in the Pilas district, near the settlements of Pilas and Concepción de Pilas, and one (Laguna Carse) located to the east in the Boruca district, roughly halfway between Pilas and Térraba. The fifth lake (Laguna Junquillo) is located north of the Río General, in the Volcán district, near the town of Volcán.

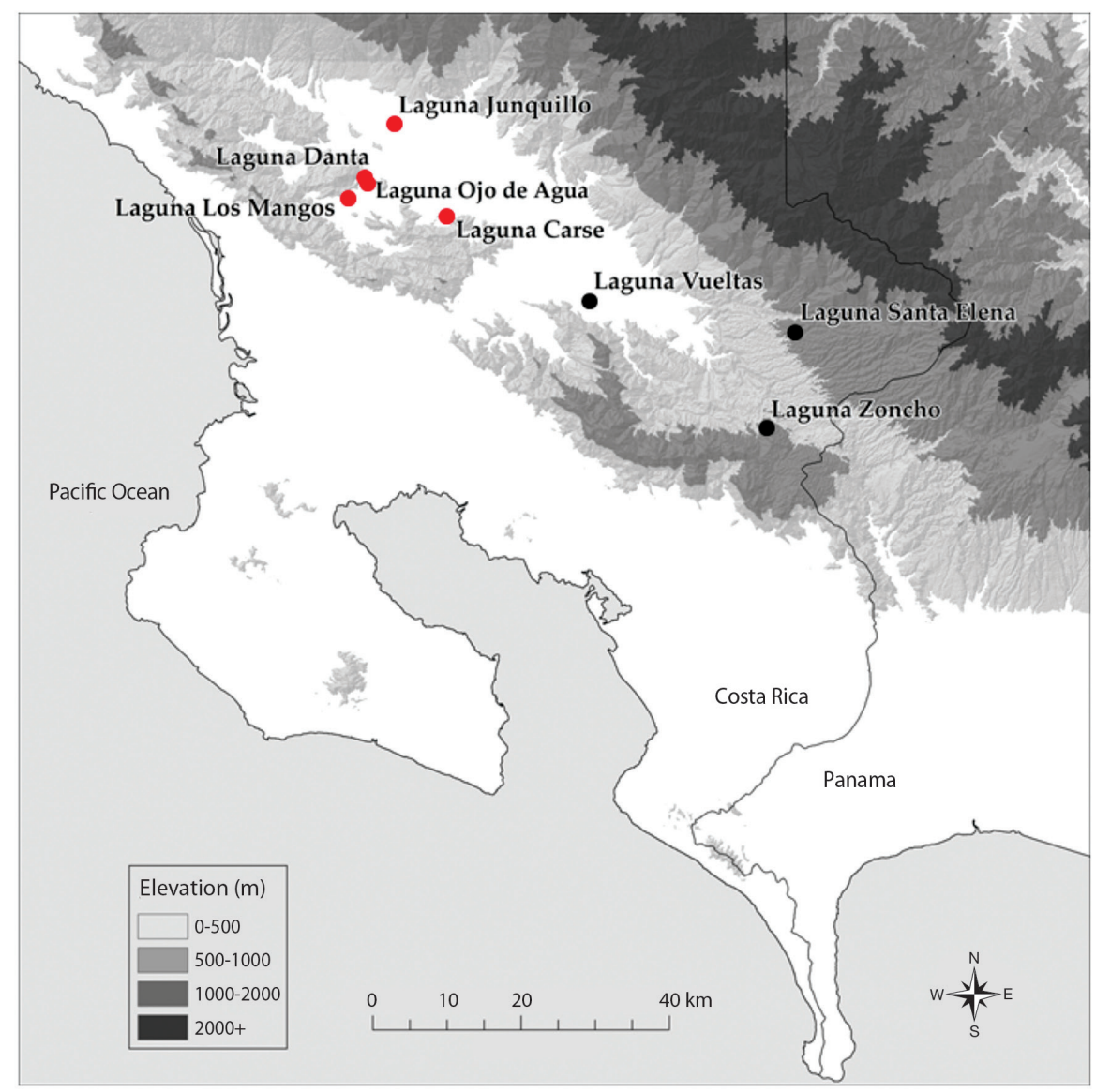

Fig. 1. Location of lake sites investigated in the southern Pacific region of Costa Rica. Red dots indicate the five lakes that are the focus of the present paper. Elevation data from CIAT-CSI SRTM (http://srtm.csi.cgiar.org). 
Lake names, where available, were taken from the 1:50000-scale topographic maps published by the Instituto Geográfico Nacional (IGN), or from nearby communities, following PREPAC (2005); we named Laguna Junquillo after a plant common along its shore. We used both the topographic maps and a hand-held GPS to estimate lake elevations. We inferred processes of lake formation from field observations, imagery available on the Google Earth ${ }^{\mathrm{TM}}$ map server, and published literature. We compiled information on the archaeological context of the lakes from archaeological site reports and field observations, and estimated distances to lake shores using the measuring tool in the Google Earth ${ }^{\mathrm{TM}}$ server. We determined Holdridge life zone classifications using the map by Tosi (1969).

We collected water and sediment samples and made depth and temperature soundings from small boats during visits in June 2013 and March and July 2014. We used a Speedtech portable depth sounder to measure water depths to the nearest 0.1 foot and created bathymetric maps of three of the lakes using a spline function in ArcGIS calculated from our field measurements. Lake areas and perimeters were determined using ArcGIS based on satellite and aerial imagery. We measured temperature with a field meter (YSI model 55), and transparency using a Secchi disk. Surface sediments were collected using a plastic scoop attached to a string of coring rods. From three of the lakes we also collected sediment cores 3-8 $\mathrm{m}$ in length using a Colinvaux-Vohnout locking-piston corer (Colinvaux, DeOliveira \& Patiño, 1999). Surface water samples for chemical analyses were collected without air and analyzed for major elements and anions at the University of Wisconsin Soil and Plant Analysis Lab using ICP-OES and Ion Chromatography, respectively. We also collected whole water surface water samples to characterize phytoplankton, adding Lugol's solution as a preservative.

We returned surface sediments in $250 \mathrm{~mL}$ Nalgene bottles and sediment cores in their original aluminum coring tubes to the Laboratory of Paleoenvironmental Research at the University of Tennessee, where they were stored in a cold room at $4-5^{\circ} \mathrm{C}$ until analysis. To characterize the surface sediments of the five lakes, we carried out loss on ignition analysis following Dean (1974). Dry sediment samples were placed in pre-weighed crucibles, weighed, and ignited in a furnace for one hour at $550^{\circ} \mathrm{C}$ to estimate organic content based on mass loss at that temperature. Following cooling and reweighing, the crucibles with sediment were placed in the furnace at 1 $000^{\circ} \mathrm{C}$ for one hour to estimate carbonate content based on mass loss between 550 and $1000^{\circ} \mathrm{C}$. We opened core tubes on a modified wood shaper and described and sampled sediments for radiocarbon dating and other analyses. We present basal radiocarbon dates from our cores in this paper as they are relevant to lake formation; other results will appear in subsequent papers focused on the paleoenvironmental data.

Phytoplankton samples were examined at Northwest Missouri State University using fixed slides. Samples were settled for at least four days, then the supernatant was siphoned off (Sukhanova, 1978). The remaining sample was mixed and $0,035 \mathrm{~mL}$ was placed on a slide and covered with a cover slip. Clear nail polish was applied to the edge to delay drying. Community composition was characterized with an Olympus $\mathrm{CH}-2$ microscope at 150x, and specimens were identified at 1000x. Taxonomic references used for identification included Thompson (1959), Bold and Wynne (1985), Krammer and Lange-Bertalot (1991), and Dillard (1999).

\section{RESULTS}

Lagunas Carse, Los Mangos, Danta, and Ojo de Agua are shown on the 1976 IGN topographic map (1:50,000-scale General sheet, Hoja 3543 III, edition 2-IGNCR). These maps were based on aerial photographs that were made in 1973, and indicate that these lakes were present at that time. However, the map shows two lakes at the Ojo de Agua site, where we found only one in our field visit and on imagery available on the Google Earth ${ }^{\mathrm{TM}}$ file server. The four lakes south of the Río General range in elevation from 365-490m, and appear to owe their formation to landslides in folded and faulted Tertiary sedimentary and volcanic rocks (Table 1).

The 1976 1:50000-scale Buenos Aires sheet (Hoja 3543 IV, edition 2-IGNCR), based on air photos taken by the IGN in 1972, shows no lake at the site of Laguna Junquillo (360m elevation). That the lake was not included on the map and has a very straight shoreline on one side suggested it was an artificial impoundment, and we encountered only a small depth of organic sediment on top of hard packed soil when we attempted to core the lake. Laguna Junquillo sits on the lower end of an alluvial fan composed of sediments eroded from the Cordillera de Talamanca (Obando \& Kussmaul, 2009a, 2009b).

Laguna Carse and Laguna Junquillo, the lakes at lowest elevation, both fall within the Holdridge tropical moist forest life zone as mapped by Tosi (1969); the other three lakes are located in the premontane wet forest life zone, where mean annual temperatures are expected to be slightly lower, and annual precipitation slightly higher. These life zone classifications are based on annual temperature and rainfall, not vegetation, but they 
TABLE 1

Lakes and their settings

\begin{tabular}{|c|c|c|c|c|c|}
\hline Lake & Lake No. ${ }^{1}$ & $\begin{array}{l}\text { Coordinates } \\
\text { (WGS 84) }\end{array}$ & $\begin{array}{l}\text { Elev. } \\
(\mathrm{m})^{2}\end{array}$ & Life Zone ${ }^{3}$ & Geology 4 \\
\hline Carse & 92 & $\begin{array}{l}9.0669^{\circ} \mathrm{N} \\
83.3472^{\circ} \mathrm{W}\end{array}$ & 365 & $\begin{array}{l}\text { Tropical moist forest, } \\
\text { near boundary with } \\
\text { premontane wet forest }\end{array}$ & $\begin{array}{l}\text { Grifo Alto formation (Upper Miocene and Pliocene } \\
\text { plutonic rocks and breccias) }\end{array}$ \\
\hline Los Mangos & 93 & $\begin{array}{l}9.0895^{\circ} \mathrm{N} \\
83.4665^{\circ} \mathrm{W}\end{array}$ & 475 & Premontane wet forest & $\begin{array}{l}\text { Curré formation comprised of Upper Miocene } \\
\text { conglomerates, sandstones, and shale }\end{array}$ \\
\hline Danta & 91 & $\begin{array}{l}9.1122^{\circ} \mathrm{N} \\
83.4480^{\circ} \mathrm{W}\end{array}$ & 470 & Premontane wet forest & $\begin{array}{l}\text { Boundary between the Curré formation (Upper } \\
\text { Miocene conglomerates, sandstones, and shale) } \\
\text { and the Grifo Alto formation (Upper Miocene and } \\
\text { Pliocene plutonic rocks and breccias) }\end{array}$ \\
\hline Ojo de Agua & 94 & $\begin{array}{l}9.1072^{\circ} \mathrm{N} \\
83.4421^{\circ} \mathrm{W}\end{array}$ & 490 & Premontane wet forest & Same as Laguna Danta \\
\hline Junquillo & 95 & $\begin{array}{l}9.1767^{\circ} \mathrm{N} \\
83.4124^{\circ} \mathrm{W}\end{array}$ & 390 & $\begin{array}{l}\text { Tropical moist forest, } \\
\text { near boundary with } \\
\text { premontane wet forest, } \\
\text { basal belt transition }\end{array}$ & Quaternary alluvial fan \\
\hline
\end{tabular}

1. Lake numbers continue the numbering system in Horn and Haberyan (2016) and correspond to numbers in a database of limnological observations from 95 Costa Rican lakes.

2. Elevation based on GPS measurements made in the field and the 1:50,000 scale topographic maps published by the Instituto Geográfico Nacional.

3. Life zone from the 1:750,000-scale map by Tosi (1969).

4. Geology from Alvarado, Taylor, Barquero, López, Cerdas and Murillo (2009a, 2009b) and Obando and Kussmaul (2009a, 2009b).

provide an indication of the types of forest that would have occupied areas surrounding the lakes prior to historic or prehistoric forest clearance. Areas surrounding or adjacent to the lakes are used today for crop cultivation and cattle grazing.

More than two dozen pre-Columbian archaeological sites are located within 1-3 Km of the four natural lakes we surveyed (Fig. 2 and Tables 2, 3, 4). Because we are interested in relationships between archaeological sites and natural lakes, we have not compiled information on sites near the modern artificial impoundment of Laguna Junquillo. Many of the archaeological sites recorded currently have an undefined chronology; however, some structures and artifacts were determined to be associated with the Aguas Buenas (500 BCE-700 CE) and Chiriquí (700-1500 CE) archaeological periods. During our field visits we observed ceramic potsherds near Laguna Danta and a stone axe near Laguna Ojo de Agua. The ceramics we observed correspond to the Aguas Buenas period.

TABLE 2

Selected pre-Columbian archaeological sites near Laguna Carse ${ }^{1}$

\begin{tabular}{|c|c|c|c|c|c|c|}
\hline Site & $\begin{array}{l}\text { No. in } \\
\text { Fig. } 2\end{array}$ & $\begin{array}{l}\text { Elev } \\
(\mathrm{m})\end{array}$ & $\begin{array}{l}\text { Area } \\
\left(\mathrm{m}^{2}\right)\end{array}$ & Function & Chronology & $\begin{array}{c}\text { Distance from } \\
\text { Laguna Carse }(\mathrm{m})\end{array}$ \\
\hline Ceibón 20 P-927 Cb-20 & 1 & 450 & 21211 & Funerary & 700-1500 CE Chiriquí Period. & 2600 \\
\hline Ceibón 21 P-928 Cb-21 & 2 & 339 & 361 & $\begin{array}{c}\text { Petroglyph and } \\
\text { possibly habitational }\end{array}$ & 700-1500 CE Chiriquí Period. & 1060 \\
\hline Bijagual 1 P-915 Pg-1 & 3 & 389 & 2332 & Petroglyph & Undefined. & 710 \\
\hline Bijagual 2 P-916 Bg-2 & 4 & 505 & 1 & Petroglyph & 500 BCE-1500 CE & 440 \\
\hline Chamancragua P-920 Cg & 5 & 400 & 1 & Petroglyph & 500 BCE-1500 CE & 390 \\
\hline Bijagual 3 P-917 Bg-3 & 6 & 453 & 1 & Petroglyph & 500 BCE-1500 CE & 1820 \\
\hline
\end{tabular}

1. All sites were described based on unsystematic inspection. Additional archaeological sites near Laguna Carse were registered by ICE archaeologists in the Orígenes data base of the Museo Nacional de Costa Rica (http://origenes.museocostarica.go.cr/busquedaGeneral.aspx). 


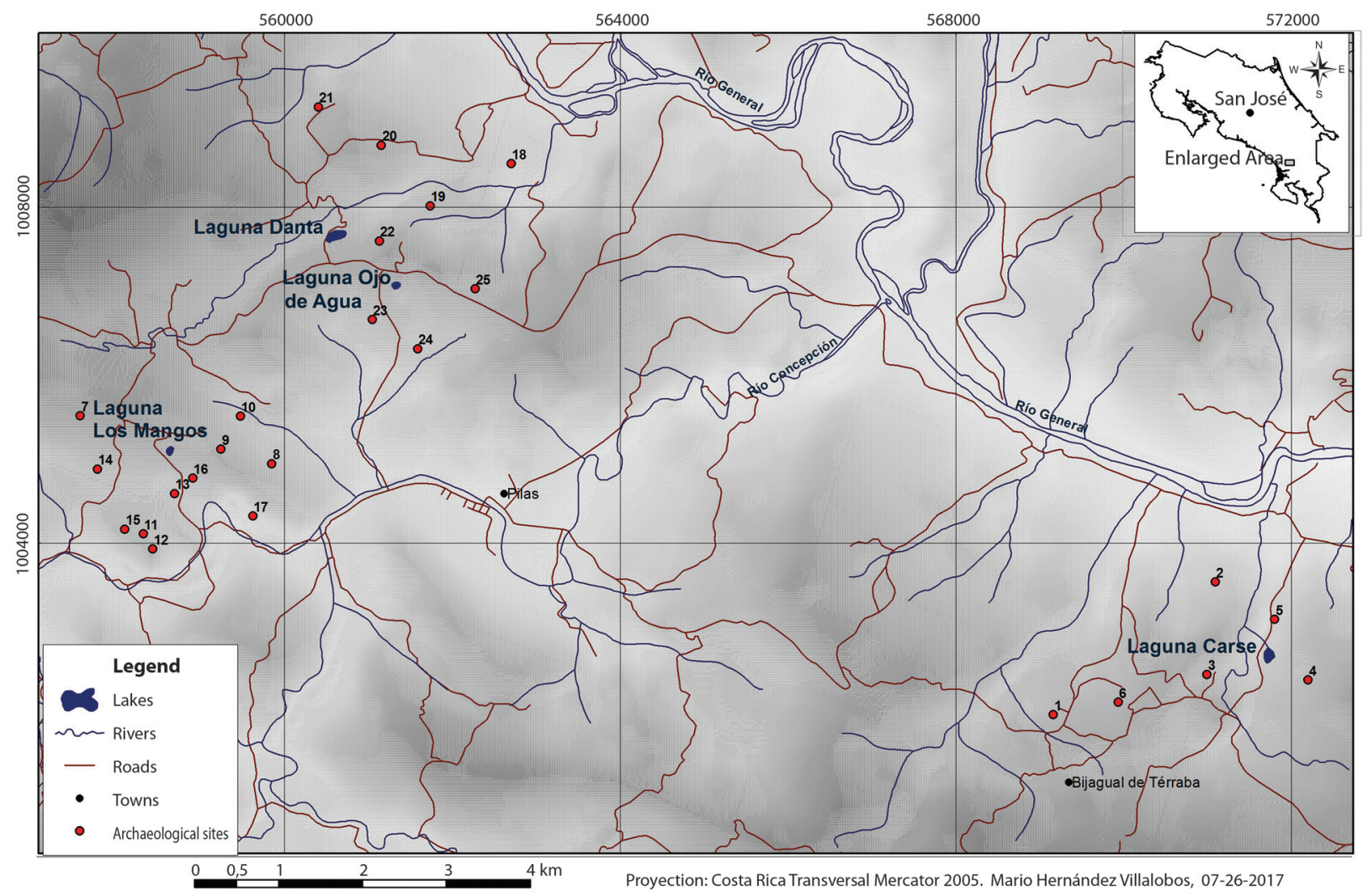

Fig. 2. Selected archaeological sites near the four natural lakes.

TABLE 3

Selected pre-Columbian archaeological sites near Laguna Los Mangos ${ }^{1}$

\begin{tabular}{|c|c|c|c|c|c|c|}
\hline Site & No. in Fig. 2 & Elev $(\mathrm{m})$ & Area $\left(m^{2}\right)$ & Function & Chronology & $\begin{array}{c}\text { Distance from Laguna } \\
\text { Los Mangos (m) }\end{array}$ \\
\hline Fila Murciélago P-963 FM & 7 & 605 & 56077 & Domestic & Undefined & 1100 \\
\hline Fila Silencio 01 P-964 FS-1 & 8 & 411 & 57535 & Domestic-Funerary & Undefined & 1200 \\
\hline Fila Silencio 02 P-965 FS-2 & 9 & 447 & 1108 & Domestic & Undefined & 580 \\
\hline Fila Silencio 03 P-966 FS-3 & 10 & 367 & 181726 & Domestic-Funerary & Undefined & 900 \\
\hline La Gloria 1 P-981 LG-1 & 11 & 419 & 787 & Funerary & Undefined & 970 \\
\hline La Gloria 2 P-982 LG-2 & 12 & 447 & 5883 & Domestic & Undefined & 1100 \\
\hline La Gloria 3, P-983 LG-3 & 13 & 379 & 1310 & Undefined & Undefined & 450 \\
\hline La Gloria 4, P-984 LG-4 & 14 & 470 & 11441 & Undefined & Undefined & 850 \\
\hline La Gloria 9, P-1430 LG-9 & 15 & 402 & 280 & Undefined & Undefined & 1000 \\
\hline Pilas 47, P-1475 PI-47 & 16 & 421 & 1 & Undefined & Undefined & 390 \\
\hline Pilas_34, P-1070 PI-34 & 17 & 267 & 2174 & Domestic-Funerary & Undefined & 1200 \\
\hline
\end{tabular}

1. All sites were described based on unsystematic inspection. Additional archaeological sites near Laguna Los Mangos were registered by ICE archaeologists in the Orígenes data base of the Museo Nacional de Costa Rica (http://origenes.museocostarica.go.cr/busquedaGeneral.aspx). 
TABLE 4

Selected pre-Columbian archaeological sites near Laguna Danta and Laguna Ojo de Agua'

\begin{tabular}{|c|c|c|c|c|c|c|c|}
\hline Site & $\begin{array}{l}\text { No. in } \\
\text { Fig. } 2\end{array}$ & $\begin{array}{l}\text { Elev } \\
(\mathrm{m})\end{array}$ & $\begin{array}{l}\text { Area } \\
\left(\mathrm{m}^{2}\right)\end{array}$ & Function & Chronology & $\begin{array}{c}\text { Distance from } \\
\text { Laguna Danta (m) }\end{array}$ & $\begin{array}{c}\text { Distance from Laguna } \\
\text { Ojo de Agua }(\mathrm{m})\end{array}$ \\
\hline Danta 1 P-950 Dt-1 & 18 & 375 & 1204 & Funerary & 500 BCE-1550 CE & 2100 & 1950 \\
\hline Danta 2 P-951 Dt-2 & 19 & 495 & 1774 & $\begin{array}{c}\text { Petroglyph and } \\
\text { possibly habitational }\end{array}$ & Undefined & 1010 & 1000 \\
\hline Danta 3 P-952 Dt-3 & 20 & 512 & 5934 & Petroglyph & Undefined & 1150 & 1680 \\
\hline Concepción 24 P-948 Cp-24 & 21 & 511 & 576 & Petroglyph & Undefined & 1540 & 2310 \\
\hline Laguna Danta P-1001 LD & 22 & 579 & 2679 & Petroglyph & Undefined & 340 & 560 \\
\hline El Oso 1 P-957 EO-1 & 23 & 471 & 7695 & Petroglyph & Undefined & 960 & 460 \\
\hline El Oso 2 P-958 EO-2 & 24 & 373 & 6221 & Petroglyph & Undefined & 1500 & 770 \\
\hline Ojo de Agua P-1033 OAg & 25 & 566 & 71133 & Petroglyph & Undefined & 1600 & 890 \\
\hline
\end{tabular}

1. Site Danta 1 was described based on a systematic investigation; all other sites were described based on unsystematic inspection. Additional archaeological sites near Laguna Danta and Laguna Ojo de Agua were registered by ICE archaeologists in the Orígenes data base of the Museo Nacional de Costa Rica (http://origenes.museocostarica.go.cr/busquedaGeneral.aspx).

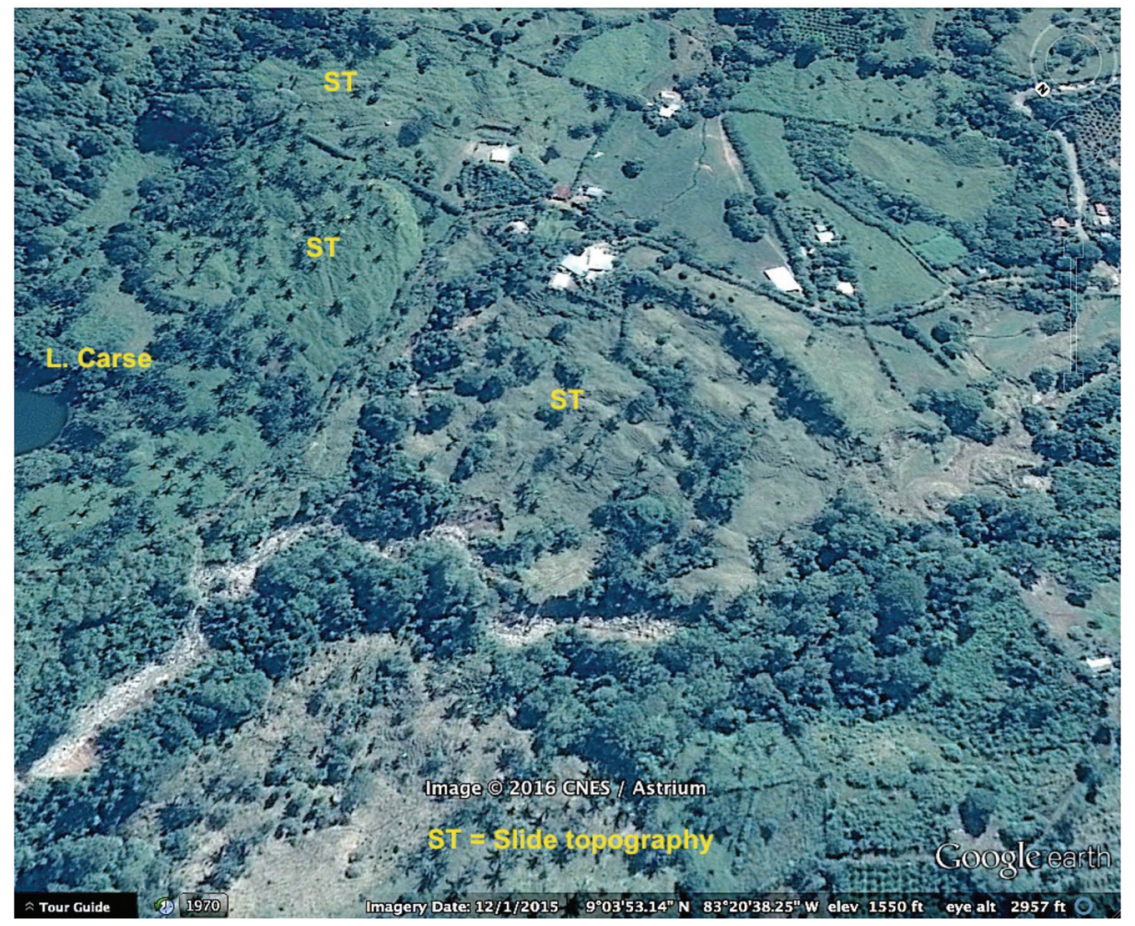

Fig. 3. Image from Google Earth ${ }^{\mathrm{TM}}$ map server showing slide topography near Laguna Carse. The conspicuously bouldery streambed of the Quebrada Moracho has picked up debris from the slides.

Alvarado et al. (2009a) mapped multiple scars from complex landslide events near our lake sites, and a deposit of colluvial sediment at Laguna Danta. We identified additional evidence of landslides at various scales on imagery from the Google Earth ${ }^{\mathrm{TM}}$ map server, especially at Laguna Carse and Laguna Danta (Figs. 3, 4). At Laguna Carse the different orientations of the hummocky debris visible in the images indicate multiple large slides in the vicinity of the lake. (Fig. 3).

Radiocarbon dates on plant remains in our sediment cores provide evidence of the timing of the landslides that formed the lake basins (Table 5). The deepest macrofossils we have dated in these cores provide minimum ages for the lake sediment records, and for the landslide 


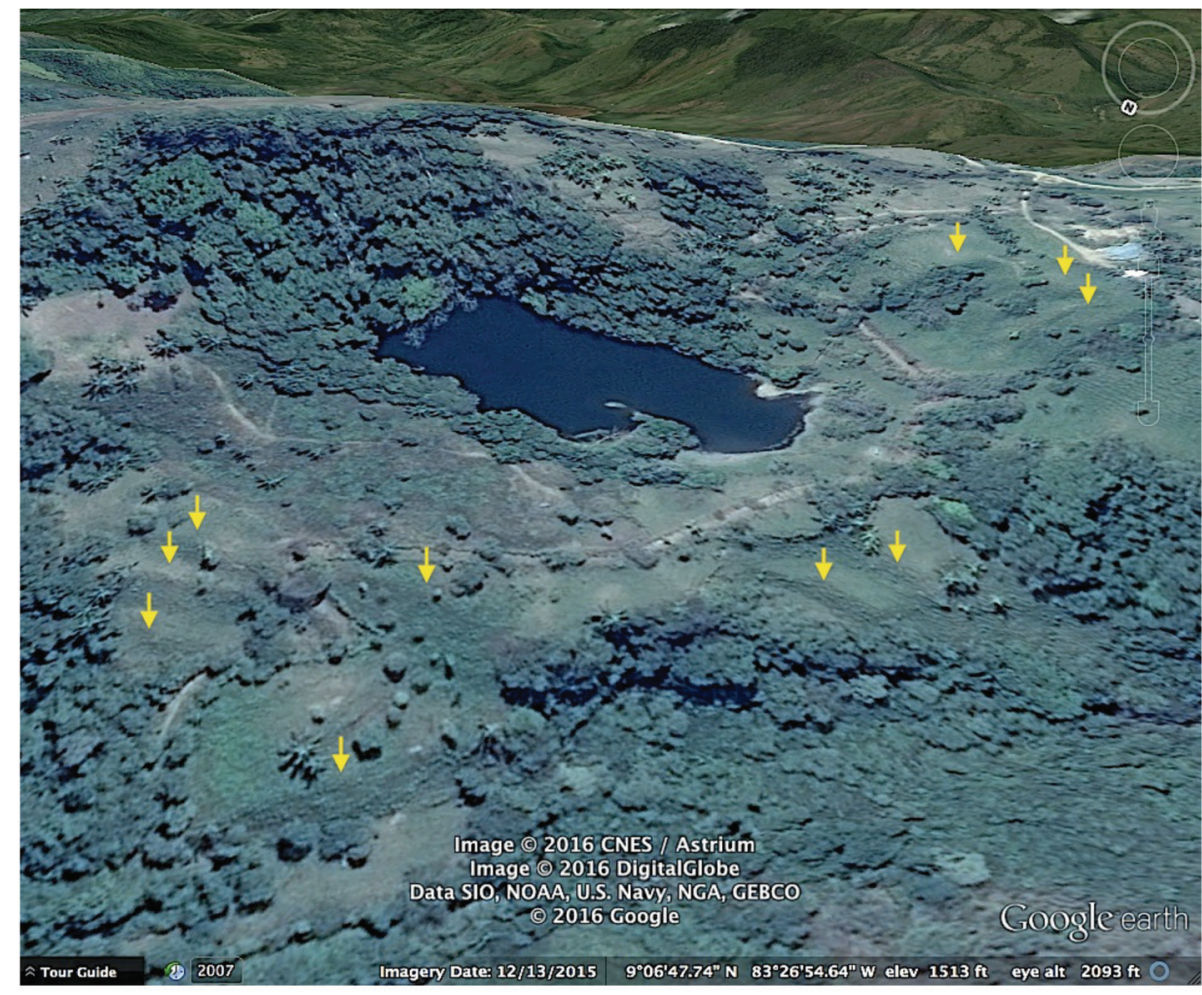

Fig. 4. Image from Google Earth ${ }^{\mathrm{TM}}$ map server showing topography suggestive of landslides near Laguna Danta.

TABLE 5

Lengths of sediment cores from lakes and basal radiocarbon dates

\begin{tabular}{|c|c|c|c|c|c|c|c|}
\hline \multirow{3}{*}{ Lake } & \multirow{3}{*}{$\begin{array}{l}\text { Core } \\
\text { Length }\end{array}$} & \multirow{3}{*}{$\begin{array}{l}\text { Depth of basal }{ }^{14} \mathrm{C} \text { date } \\
\text { and material dated }\end{array}$} & \multirow{3}{*}{ Lab No. ${ }^{1}$} & \multirow{3}{*}{$\begin{array}{l}\text { Uncalibrated Age } \\
\qquad\left({ }^{14} \mathrm{C} \text { yr BP }\right)\end{array}$} & \multicolumn{3}{|c|}{ Calibrated Ages ${ }^{2}$} \\
\hline & & & & & \multirow{2}{*}{$\begin{array}{l}95 \% \text { Range } \\
\text { (cal yr BP) }\end{array}$} & \multicolumn{2}{|c|}{ Weighted mean ages } \\
\hline & & & & & & BP scale & BCE/CE scale \\
\hline Laguna Carse & $7.14 \mathrm{~m}$ & $6.96 \mathrm{~m} ;$ wood & UGAMS 19460 & $350 \pm 20$ & $487-316$ & 398 cal yr BP & 1552 CE \\
\hline Laguna Los Mangos & $7.60 \mathrm{~m}$ & $7.34 \mathrm{~m}$; bark & UGAMS 19461 & $3760 \pm 25$ & $4231-3997$ & 4122 cal yr BP & $2172 \mathrm{BCE}$ \\
\hline Laguna Danta & $4.34 \mathrm{~m}$ & $3.53 \mathrm{~m}$; leaf & D-AMS 014531 & $677 \pm 25$ & $676-563$ & 629 cal yr BP & $1321 \mathrm{CE}$ \\
\hline
\end{tabular}

1. Analyses were performed by the Center for Applied Isotope Studies at the University of Georgia (UGAMS) and by Direct AMS.

2. Calibrations were made using CALIB version 7.0.2 (Stuiver \& Reimer, 1993) and the IntCal 13 calibration dataset (Reimer et al., 2013). The weighted mean age was calculated from CALIB output.

events that formed the basins. These ages indicate lake formation prior to ca. 400 cal yr BP (calibrated years before CE 1950) at Laguna Carse, that is, before the year 1550 CE in the CE/BCE time scale. Laguna Danta formed before 630 cal yr BP (1320 CE). Laguna Los Mangos, which also appears to have formed in connection with land slumping or sliding, formed much earlier than the other lakes investigated. The lowest plant macrofossil we dated in the sediment core yielded a radiocarbon date that corresponds to 4120 cal yr BP (2170 BCE). Laguna Ojo de Agua, which we did not core, has a basin morphology and setting that also suggests formation associated with a landslide event.

Wet season water depths varied from less than 0.5 $\mathrm{m}$ at Laguna Los Mangos to $5 \mathrm{~m}$ at Laguna Danta and Laguna Carse (Table 6; Fig. 5). From our repeat photography and observations along shorelines we estimate that water levels in March 2014 were at least $0.2 \mathrm{~m}$ lower at Laguna Los Mangos and ca. 0.3-0.4 m lower at Laguna Danta and Laguna Junquillo than in July 2014. We do not have repeat photographs adequate to compare water levels at Laguna Carse in March 2014 with our 


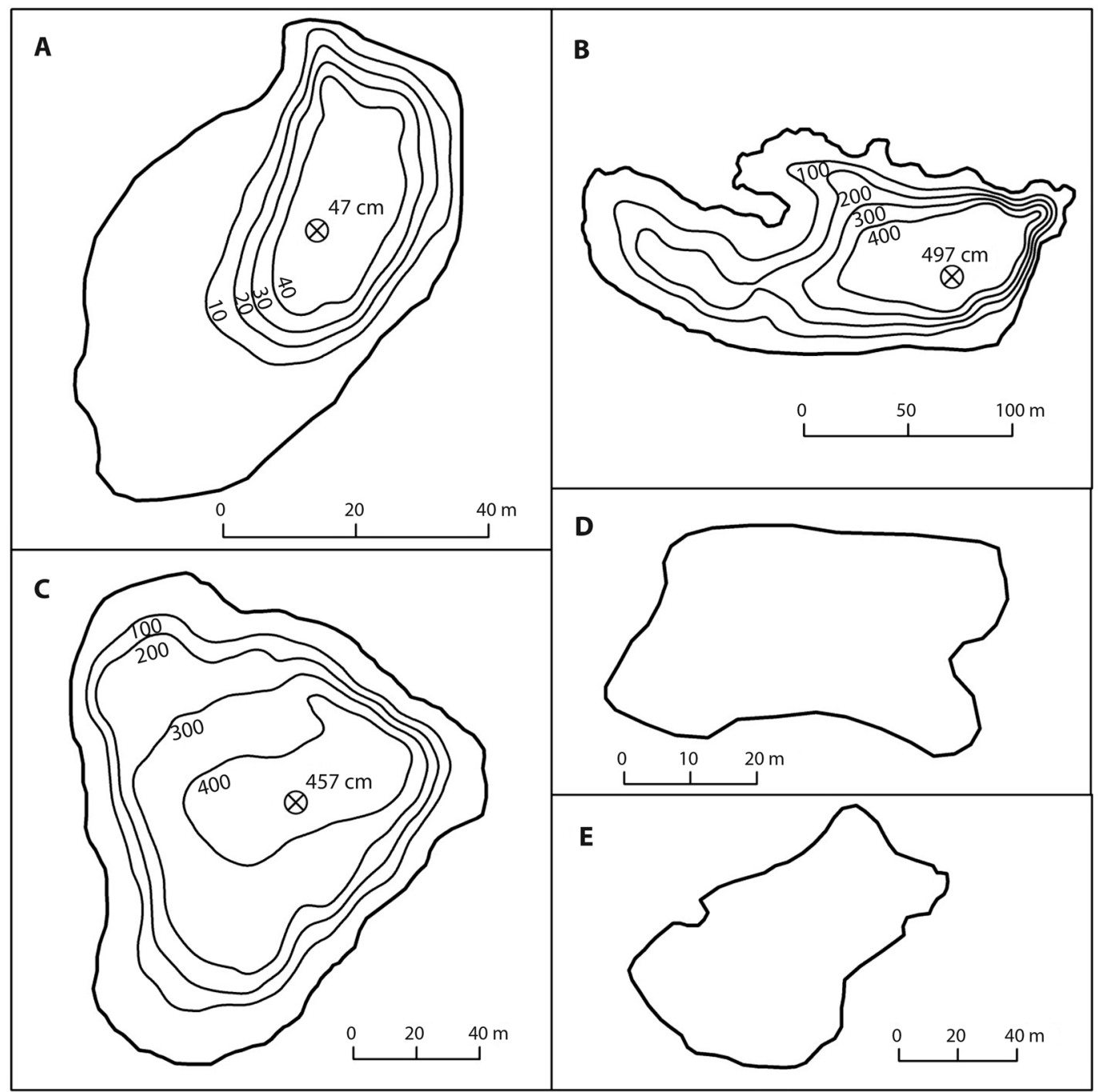

Fig. 5. Bathymetric maps of A. Laguna Los Mangos, B. Laguna Danta, and C. Laguna Carse, and outlines of D. Laguna Ojo de Agua and E. Laguna Junquillo. Depths are in centimeters. Positions and depths of sediment coring locations are shown by circles with Xs. We measured a maximum depth of $263 \mathrm{~cm}$ near the center of Laguna Ojo de Agua, and a maximum depth of $350 \mathrm{~cm}$ near the southwestern end of Laguna Junquillo.

measurements in July 2014. Water level at Laguna Danta in June 2013 was ca. $10 \mathrm{~cm}$ lower than in July 2014, based on comparison photographs.

We made temperature readings only in July 2014 and our results (Fig. 6) showed that none of the lakes was stratified at this time. Ojo de Agua was completely covered in floating aquatic plants (mainly Lemna), and showed the lowest temperatures and lowest transparency. Water samples from July 2014 showed that all five lakes were circum-neutral in $\mathrm{pH}$ (Table 7). In these lakes the most abundant elements are $\mathrm{Ca}, \mathrm{Na}, \mathrm{Mg}$, and $\mathrm{K}$, and the most abundant anions are chloride and sulfate, with sulfate levels especially high at Laguna Los Mangos and Laguna Danta. Laguna Los Mangos showed the highest alkalinity.

Our analysis of phytoplankton in whole water samples revealed diversity in composition across the five lakes (Table 8, Fig. 7). The single taxon estimated to have the highest biomass differed at each site, but there was overlap among the top three taxa, which were identical for Laguna Danta and Laguna Carse (Peridinium, Trachelomonas, Cryptomonas).

Loss on ignition analysis revealed similar organic matter content in the surface lake sediments (range 22,1$28,8 \%$, mean $24,7 \%$, calculated on a dry mass basis), with highest values at Laguna Danta (Fig. 8). Estimated 
TABLE 6

Physical properties of lakes

\begin{tabular}{|c|c|c|c|c|c|}
\hline & Laguna Carse & Laguna Los Mangos & Laguna Danta & Laguna Ojo de Agua & Laguna Junquillo \\
\hline Area (ha) & 1,5 & 0,3 & 1,7 & 0,2 & 0,5 \\
\hline Volume $\left(\mathrm{m}^{3}\right)$ & 31224 & 441 & 34190 & & \\
\hline Shoreline length (m) & 463 & 208 & 699 & 163 & 309 \\
\hline Shoreline development ${ }^{1}$ & 1,07 & 1,07 & 1,51 & 1,03 & 1,23 \\
\hline Depth $(\mathrm{m})^{2}$ & 5,0 & 0,5 & 5,0 & 2,6 & 3,5 \\
\hline Mean depth $(\mathrm{m})^{3}$ & 2,08 & 0,15 & 2,01 & & \\
\hline Secchi depth (m) & 1,41 & $>0,50$ & 1,04 & 0,62 & 1,19 \\
\hline Stratification & no & no & no & no & no \\
\hline Surface temperature $\left({ }^{\circ} \mathrm{C}\right)$ & 31,0 & 30,7 & 30,5 & 27,2 & 30,0 \\
\hline
\end{tabular}

1. Shoreline development is the ratio of the length of the shoreline to the circumference of a circle with an area equal to the area of the lake. The value provides an indication of the potential for the development of littoral plant communities. The formula is $L / A$ ) in which $L$ is shoreline length and $A$ is lake area in corresponding units, for example, meters and square meters.

2. Depth at Laguna Danta was measured in June 2013; all other depths are from July 2014.

3. Mean depth corresponds to lake volume divided by lake area.

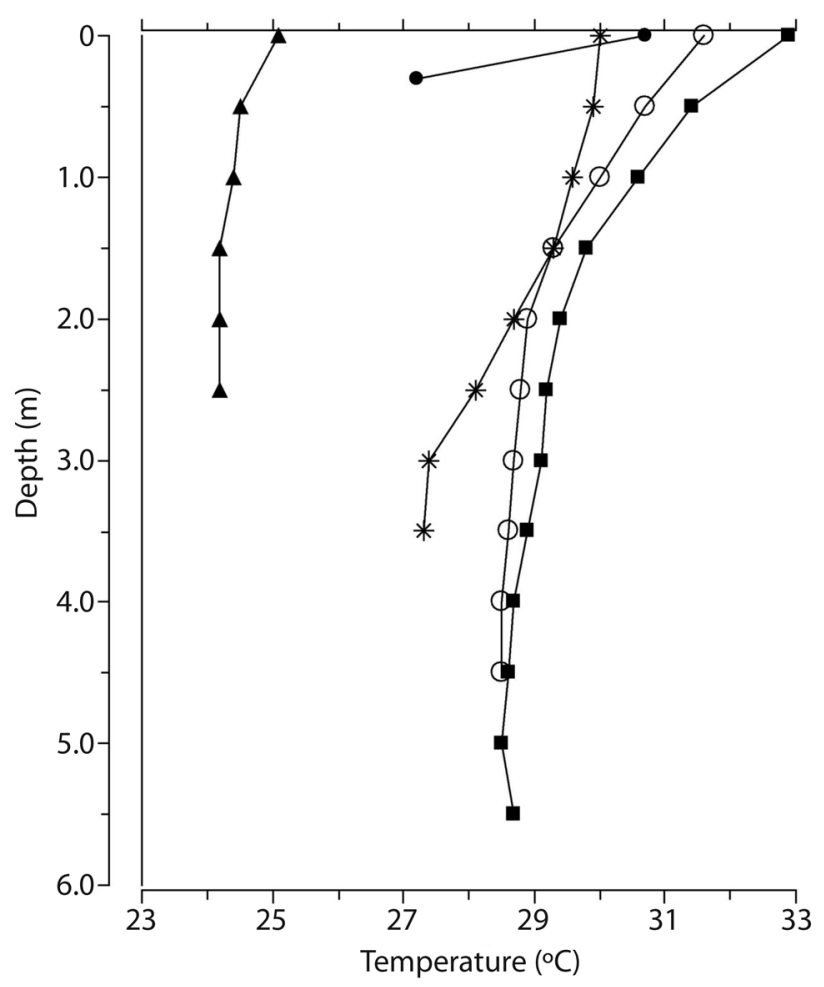

Fig. 6. Lake temperature profiles. Data were collected between July 20 and July 25, 2014 from Lagunas Ojo de Agua (solid triangle symbol), Los Mangos (solid circle), Junquillo (stars), Carse (open circles), and Danta (solid squares). carbonate values were low and also similar, ranging from $2,0-4,3 \%$ (mean $2,8 \%$ ).

\section{DISCUSSION}

Our original intent was to sample only natural lakes in the cantón of Buenos Aires, to build on the lake-sediment studies of Holocene environmental history that we have carried out at other lakes in the region (Lagunas Vueltas, Zoncho, and Santa Elena: Fig. 1; and Horn \& Haberyan (2016) and references therein). We were introduced to Laguna Junquillo by a local researcher, who understood the lake to be natural and referred to it as Laguna Tadeo. We subsequently discovered Laguna Tadeo to be the name associated with a seasonal lake shown on the IGN Buenos Aires topographic map approximately $1 \mathrm{Km}$ southeast of Laguna Junquillo. Both sites are on the Río Cañas alluvial fan, interpreted to have formed following deglaciation of the Cordillera de Talamanca (Obando \& Kussmaul, 2009a), which occurred between 12360 and 9700 cal yr BP based on radiocarbon dates on basal sediments in glacial lakes on Cerro Chirripó (Orvis \& Horn, 2000). We were unable to visit the site of the real Laguna Tadeo during our field work at area lakes, but imagery on the Google Earth ${ }^{\mathrm{TM}}$ server suggests the lake may still exist. If so, it may preserve sediments useful for studying past climates and environments, possibly for a significant period of time, if the lake is as old as the fan on which it sits. 
TABLE 7

Chemical properties of lakes

\begin{tabular}{|c|c|c|c|c|c|}
\hline & Laguna Carse & Laguna Los Mangos & Laguna Danta & Laguna Ojo de Agua & Laguna Junquillo \\
\hline \multicolumn{6}{|l|}{ Cations (ppm) } \\
\hline $\mathrm{P}$ & $<0,05$ & 0,3 & 0,2 & $<0,05$ & $<0,05$ \\
\hline K & 3,30 & 3,19 & 5,29 & 8,14 & 0,55 \\
\hline $\mathrm{Ca}$ & 29,93 & 65,91 & 26,70 & 24,13 & 2,26 \\
\hline $\mathrm{Mg}$ & 8,90 & 8,23 & 3,32 & 3,93 & 0,49 \\
\hline$S$ & 0,46 & 4,98 & 3,72 & 0,58 & 0,12 \\
\hline $\mathrm{Zn}$ & $<0,001$ & 0,01 & $<0,001$ & $<0,001$ & $<0,001$ \\
\hline$B$ & $<0,02$ & $<0,02$ & 0,04 & $<0,02$ & $<0,02$ \\
\hline $\mathrm{Mn}$ & $<0,001$ & $<0,001$ & $<0,001$ & 0,06 & $<0,001$ \\
\hline $\mathrm{Fe}$ & 0,001 & 0,004 & $<0,001$ & 0,16 & 0,68 \\
\hline $\mathrm{Cu}$ & $<0,005$ & 0,03 & 0,01 & 0,02 & $<0,005$ \\
\hline $\mathrm{Al}$ & $<0,05$ & $<0,05$ & $<0,05$ & 0,07 & 0,05 \\
\hline $\mathrm{Na}$ & 6,50 & 26,70 & 24,31 & 16,15 & 2,37 \\
\hline $\mathrm{Cd}$ & $<0,004$ & $<0,004$ & $<0,004$ & $<0,004$ & $<0,004$ \\
\hline Co & $<0,003$ & $<0,003$ & $<0,003$ & $<0,003$ & $<0,003$ \\
\hline $\mathrm{Cr}$ & $<0,001$ & $<0,001$ & $<0,001$ & $<0,001$ & $<0,001$ \\
\hline Mo & $<0,004$ & $<0,004$ & 0,004 & $<0,004$ & $<0,004$ \\
\hline $\mathrm{Ni}$ & $<0,003$ & $<0,003$ & $<0,003$ & $<0,003$ & $<0,003$ \\
\hline $\mathrm{Pb}$ & $<0,02$ & $<0,02$ & $<0,02$ & $<0,02$ & $<0,02$ \\
\hline $\mathrm{Li}$ & $<0,001$ & 0,002 & 0,002 & 0,002 & $<0,001$ \\
\hline As & $<0,03$ & $<0,03$ & $<0,03$ & $<0,03$ & $<0,03$ \\
\hline Se & $<0,03$ & $<0,03$ & $<0,03$ & $<0,03$ & $<0,03$ \\
\hline $\mathrm{Ba}$ & 0,05 & 0,04 & 0,01 & 0,07 & 0,01 \\
\hline \multicolumn{6}{|l|}{ Anions (ppm) } \\
\hline $\mathrm{F}^{-}$ & 0,45 & $<0,01$ & $<0,01$ & $<0,01$ & $<0,01$ \\
\hline $\mathrm{Cl}^{-}$ & 4,63 & 3,00 & 3,47 & 1,72 & 1,71 \\
\hline $\mathrm{NO}_{2}^{-}$ & $<0,01$ & $<0,01$ & $<0,01$ & $<0,01$ & $<0,01$ \\
\hline $\mathrm{Br}^{2}$ & $<0,01$ & $<0,01$ & $<0,01$ & $<0,01$ & $<0,01$ \\
\hline $\mathrm{NO}_{3}^{-}$ & 2,07 & 1,63 & $<0,01$ & $<0,01$ & $<0,01$ \\
\hline $\mathrm{PO}_{4}^{3-}$ & $<0,02$ & $<0,02$ & $<0,02$ & $<0,02$ & $<0,02$ \\
\hline $\mathrm{SO}_{4}^{2-}$ & 1,08 & 10,09 & 10,60 & 0,32 & $<0,02$ \\
\hline Alkalinity (ppm $\left.\mathrm{CaCO}_{3}\right)$ & 118,8 & 212,5 & 112,5 & 125,0 & 12,5 \\
\hline $\mathrm{pH}$ & 7,4 & 7,3 & 7,8 & 7,1 & 7,3 \\
\hline
\end{tabular}

Our interpretation that landslides created the four natural lakes we investigated is in keeping with local geomorphology and geology (Alvarado et al., 2009a, 2009b) and with the formation of other lakes we have investigated in the region. Sitchler, Fisher, Gardner and Protti (2007) tied the existence of very large landslides in the southern Pacific region to deformation of the Fila Costeña caused by the subduction of the Cocos Plate. Repeated landslides in the watershed of Laguna Carse may have contributed to the anomalously rapid infilling of the lake by disturbing forests and exposing mineral soil. Based on the age of the wood we radiocarbon-dated near the base of our sediment core, Laguna Carse has accumulated $7 \mathrm{~m}$ of sediment since it formed near the time of the Spanish Conquest, indicating an average accumulation rate of ca. $1,4 \mathrm{~cm} / \mathrm{yr}$. This rate is far higher than those we have found in dozens of cores from widespread locations in Costa Rica. Infilling was also rapid at Laguna Santa Elena, a much smaller lake $(0,13 \mathrm{ha}) 50 \mathrm{Km}$ east southeast of Laguna Carse (Horn \& Haberyan, 2016). A sediment core from Laguna Santa Elena revealed the position of the Spanish Conquest to be at a sediment depth of ca. $2,7 \mathrm{~m}$ 


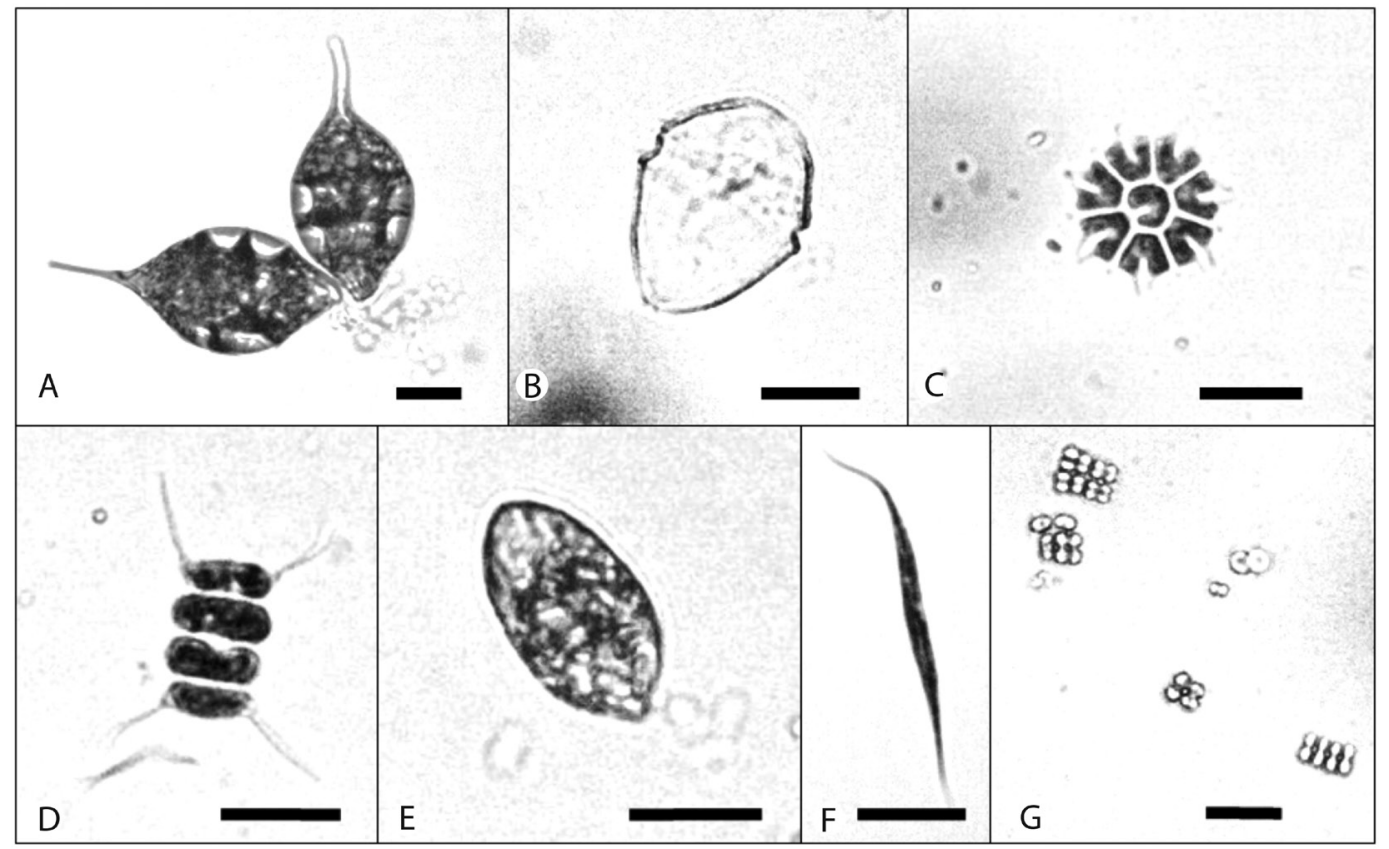

Fig. 7. Selected plankton at study sites: Phacus (A) in sample from Laguna Los Mangos; Peridinium (B), Pediastrum obtusum (C), Scenedesmus (D), and Cryptomonas (E) from Laguna Danta; Ankistrodemis (F) from Laguna Junquillo; and Merismopedia (G) from Laguna Ojo de Agua. All scale bars are 10 micrometers.

TABLE 8

Phytoplankton in lakewater samples*

\begin{tabular}{|c|c|c|c|c|c|}
\hline Taxon & Laguna Los Mangos & Laguna Danta & Laguna Ojo de Agua & Laguna Carse & Laguna Junquillo \\
\hline \multicolumn{6}{|l|}{ Cryptophyta } \\
\hline Cryptomonas & & 3 & & 3 & 2 \\
\hline \multicolumn{6}{|l|}{ Diatoms } \\
\hline Pinnularia & + & & & & \\
\hline Gomphonema & + & & & & \\
\hline Nitzschia & + & & & & \\
\hline Naviculaceae & & & + & & \\
\hline Aulacoseira & + & & & & \\
\hline \multicolumn{6}{|l|}{ Dinoflagellates } \\
\hline Peridinium & & 1 & & 2 & \\
\hline \multicolumn{6}{|l|}{ Chlorophytes } \\
\hline Closterium & + & & & & \\
\hline Desmidaceae & & & & & 3 \\
\hline Pediastrum obtusum & & + & & & \\
\hline Ankistrodesmus & & & & & 1 \\
\hline Scenedesmus & & + & & & \\
\hline \multicolumn{6}{|l|}{ Protozoa } \\
\hline Trachelomonas & & 2 & & 1 & \\
\hline Phacus & 1 & & 3 & & \\
\hline \multicolumn{6}{|l|}{ Cyanobacteria } \\
\hline Aphanizomenon & 3 & & & & \\
\hline Merismopedia & & & 1 & & \\
\hline Oscillatoria & 2 & & 2 & & \\
\hline
\end{tabular}

* Numbers 1, 2, and 3 indicate relative biomass for the three most abundant taxa in each lake. + denotes taxa also observed in samples. 

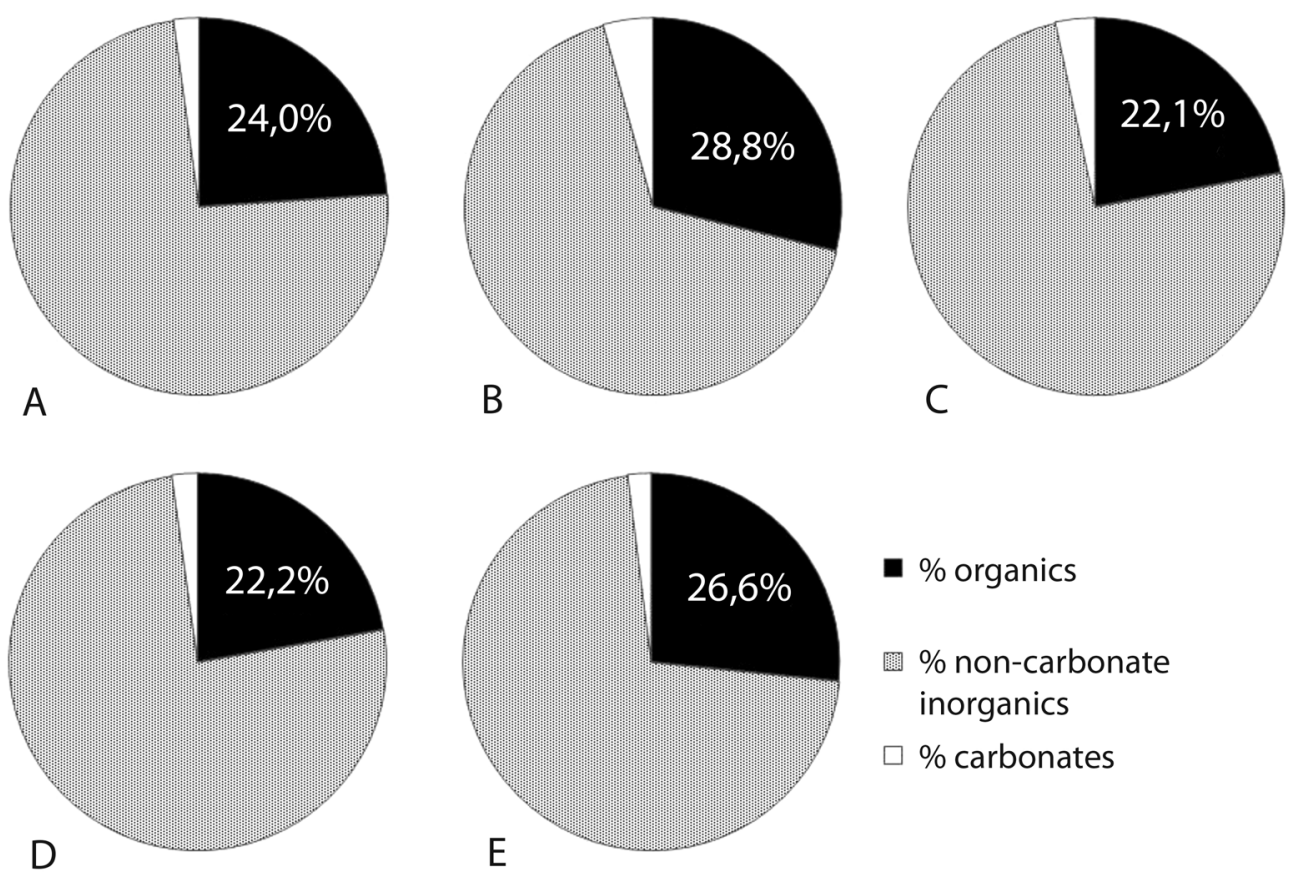

$\%$ organics

$\%$ non-carbonate inorganics

$\%$ carbonates

Fig. 8. Composition of surface lake sediment samples based on loss on ignition analysis. Percentages expressed on a dry mass basis. A. Laguna Los Mangos. B. Laguna Danta. C. Laguna Ojo de Agua. D. Laguna Carse. E. Laguna Junquillo.

(Anchukaitis \& Horn, 2005), indicating a post-Conquest sedimentation rate of $0,6 \mathrm{~cm} /$ year, which is less than half the rate at Laguna Carse. Multiple cores from Laguna Zoncho $(50 \mathrm{Km}$ southeast of Laguna Carse; Clement \& Horn, 2001; Taylor, Horn \& Finkelstein, 2015) indicate an average post-Conquest sedimentation rate of ca. $0,2 \mathrm{~cm} /$ $y r$. The extreme rate of sediment accumulation in Laguna Carse, which was 2,5-7 times faster than at other lakes in the southern Pacific region of Costa Rica, likely also reflects post-Conquest deforestation and agricultural use of the lake basin, including by indigenous Terraba people who were relocated to the vicinity of Laguna Carse by the Spanish in the late $17^{\text {th }}$ century (Stone, 1962).

Our compilation and examination of archaeological site reports confirms the presence of archaeological structures, petroglyphs, and funerary and habitational sites near the four natural lakes. Archaeological evidence predates the formation of Laguna Danta during the latter part of the Chiriquí archaeological period, and of Laguna Carse near the time of the Spanish Conquest. When these lakes formed they would have become resources for people already living nearby, and perhaps some people moved closer to the new lakes in response to the availability of this resource. But these lakes formed on a landscape already inhabited by people, as shown by the ages of artifacts and sites near the lakes. At Laguna Los Mangos, however, the weighted mean age of 4122 cal yr BP (2172 BCE) for a piece of tree bark near the base of our 7,6m long sediment core exceeds the age of the earliest known archaeological sites in the region. In this case, the lake formed prior to human presence in the area, allowing us to infer the timing and nature of initial prehistoric human settlement and land-use through the study of preserved pollen grains, charcoal fragments, stable isotope signatures, and other indicators in the lake sediments, as we have done at other sites in Costa Rica (Horn \& Haberyan, 2016).

Three of the natural lakes we sampled, Lagunas Danta, Ojo de Agua, and Carse, were mentioned in a 2005 inventory of water bodies in Costa Rica that emphasized the development of fishing and aquaculture (PREPAC, 2005), and in an earlier compilation by government agencies (Córdoba Muñoz et al., 1998). These sources list the area of Lagunas Danta and Ojo de Agua as 5 and 0,5ha, respectively, values two to three times higher than we determined in our analysis using ArcGIS, but the area they list for Carse $(1,5 \mathrm{ha})$ matches our determination. While the PREPAC inventory team visited both lakes, they did not collect limnological data or samples. The earlier lake inventory (Córdoba Muñoz et al., 1998) seems to have included very little field work, but did list a depth for Laguna Danta of $3 \mathrm{~m}$. The source of this datum is not clear; we measured a maximum depth of $5 \mathrm{~m}$ in June 2013 and at least $4.7 \mathrm{~m}$ in March 2014. Whether the depth of $3 \mathrm{~m}$ 
represents an actual measurement or an estimate based on conversations with locals is unknown. Citing the 1998 report, PREPAC (2005) also reported 3m as the depth of Laguna Danta, but presented the value as a mean depth. This is a typographical error because in limnology mean depth is not an observation, but a variable calculated by dividing the volume of a lake by its surface area. From our GIS and bathymetric analyses we calculate the mean depth at Laguna Danta to be $2 \mathrm{~m}$ (Table 5).

During their visit to Laguna Ojo de Agua during August-October 2004, the PREPAC team found the lake surface to be fully covered by 'lechuguilla de agua.' This common name is sometimes used for the aquatic plant Pistia stratioites, but more typically Pistia stratioites is called 'lechuga de agua'. Pistia has much bigger leaves than Lemna and the photograph from 2005 suggests a smaller-leaved plant. The dominant plant in 2005 may have been Lemna, as it was in 2014.

Lake water temperatures at the five sites are in keeping with observations at lakes throughout Costa Rica (Horn \& Haberyan, 1993, 2016; Umaña et al., 1999; Haberyan et al., 2003). All five of these lakes are small, and are probably polymictic lakes that turn over frequently. The water chemistry data are also similar to previous surveys. These five lakes in the Buenos Aires cantón showed undetectable concentrations of many elements, providing benchmarks to assess any future changes in lake chemistry due to changes in forest cover, land use, human population density, air pollution, or climate change.

Phytoplankton samples from the five lakes included genera that were previously reported in other shallow, low-altitude Costa Rican lakes (Haberyan, Umaña, Collado, \& Horn, 1995), but not as dominant genera. For example, we found Phacus to dominate Laguna Los Mangos (Table 8), but in the wet-season survey of 30 lakes by Haberyan et al. (1995) this genus was uncommon in the four lakes in which it occurred, ranking as the fifth most dominant taxon in only one lake. Similarly, Ankistrodesmus was a widespread, subdominant (rank 2-4) genus in the earlier survey, but we found it to dominate Laguna Junquillo. With the notable exception of the detailed weekly sampling of phytoplankton at several lakes by Umaña (2010, 2014, 2016), most sampling of phytoplankton in Costa Rican lakes has been episodic or limited to a single visit, hampering understanding of phytoplankton ecology. Sampling at higher frequency and across multiple seasons at more lakes will be required to document relationships between phytoplankton and lake characteristics across climate and ecological zones of Costa Rica.

Our loss on ignition analyses showed low apparent carbonate content in the surface sediments of the five lakes, an expectation where carbonate bedrock is rare or absent. The low values we found may have been affected by clay minerals in the sediments. Dean (1974) noted that most clays contain up to $5 \%$ lattice water, which is driven off between $550^{\circ} \mathrm{C}$ and $1000^{\circ} \mathrm{C}$. Loss on ignition analysis of sediment samples that are high in clay can show $3-4 \%$ mass loss between $550^{\circ} \mathrm{C}$ and $1000^{\circ} \mathrm{C}$, even if no carbonate is present. X-Ray diffraction and other geochemical methods could provide more accurate measurements of the carbonate content of the inorganic sediments, but from our loss on ignition data we know that values are low.

The organic matter content of the surface sediments of the five lakes falls near the middle of the range of a set of 57 Costa Rican lakes (Fig. 9). The amount of organic matter in surface lake sediments is determined by many factors. These include the productivity of aquatic organisms and littoral plants; the input of organic matter produced from outside of the lake; and inorganic inputs, which dilute organic matter percentages in sediments (Shuman, 2003). Organic productivity and mineral input are affected by soils and climate. Natural disturbances such as landslides and wildfires, and human actions such as forest clearance, the establishment and maintenance of agriculture fields, and the creation of footpaths, house yards, or other features with hard-packed surfaces can increase soil erosion and transport of mineral sediments to lakes by exposing mineral soil, reducing soil infiltration capacity, and enhancing surface runoff (Harden, 1992; Wallin \& Harden, 1996).

Other processes that can influence sediment organic content include decomposition of organic matter and sediment focusing, a limnological process that can lead to increased rates of sediment accumulation in central portions of lake basins, potentially altering sediment composition (Shuman, 2003). Because multiple watershed characteristics and processes within and outside of lakes influence the organic content of sediments, it is possible for two lakes with similar sediment composition to have arrived at that condition in different ways. Lake $A$ may have much higher aquatic productivity than Lake $B$, but similar sediment composition if Lake $A$ also exceeds Lake $B$ in the input of mineral matter from surface runoff and inflowing streams.

Without additional study it is premature to read too much into the central position of these new five lakes in the larger dataset of organic matter content shown in Figure 9. However, as a broad generalization, we can conclude that the present balance between fluxes and preservation of organic and inorganic matter is somewhat similar across the five lakes, perhaps driven by the 


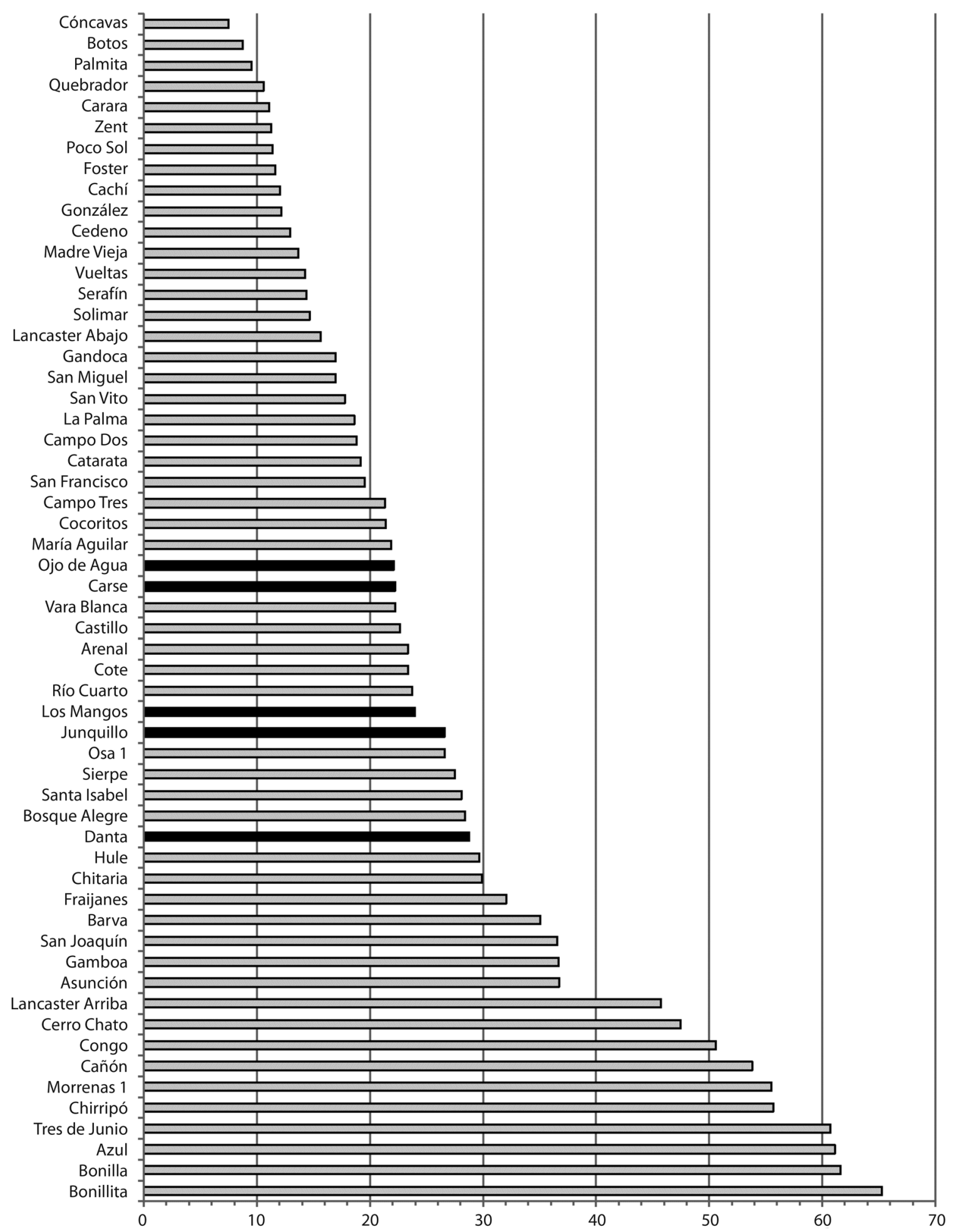

Fig. 9. Organic matter content (percent dry mass) of surface sediments of the five lakes (black bars) compared to other lakes in Costa Rica (light gray bars). Data are from Rodgers and Horn (1996) and Horn (unpublished). 
similar climate and land use at the sites. The geomorphic setting of the four natural lakes, each associated with one or more landslides, is also similar. For the three lakes from which we have sediment cores, marked variations in loss on ignition downcore show that these balances have changed over time, leading to intervals in which accumulating sediments have organic contents much higher or lower than surface values. These changes were likely influenced by changes in climate, natural disturbance regimes, human activity, and lake levels over the histories of the lakes (Shuman, 2003).

Our investigation of the limnology and setting of four natural lakes and one artificial impoundment in southern Pacific Costa Rica adds to knowledge of lake characteristics and diversity in Costa Rica. Our observations provide context for our analyses of sediment records from these lakes. Lakes and wetlands in Costa Rica are an important resource for humans and wildlife, and contribute to overall biodiversity across all ecosystem regions. Our study provides benchmarks for assessing future changes in these lakes and their watersheds resulting from human activity, natural disturbances, and regional and global climate change.

\section{ACKNOWLEDGMENTS}

Field work and laboratory analyses were supported by the Initiative for Quaternary Paleoclimate Research at the University of Tennessee; by research funds provided to SPH by a Chancellor's Professorship and by the Betty Lynn Hendrickson Professorship at the University of Tennessee; and by grants to ENJ from the Biogeography and Paleoenvironmental Change Specialty Groups of the American Association of Geographers, and from the Stewart F. McCroskey Fund at the University of Tennessee. We thank the government of Costa Rica, land owners, and the Térraba indigenous community council for permission to sample lakes, and Matthew Kerr, María José Rivera Araya, María López Rojas, and archaeologists and staff of the Proyecto Hidroeléctrico El Diquís of the Instituto Costarricense de Electricidad for field assistance. We acknowledge the contributions of Theodore Oberlander, who helped us interpret site geomorphology, and of Orlando Vargas Ramírez, who identified the shoreline plant after which we named Laguna Junquillo. Finally, we thank the reviewers and editor, whose suggestions helped us improve the manuscript.

\section{REFERENCES}

Alvarado, G. E., Taylor, W., Barquero, R., López, A., Cerdas, A., \& Murillo, J. (2009a). Mapa geológico de la hoja General. Serie Colección de mapas geológicos (9). Revista Geológica de América Central, 40, 9.

Alvarado, G. E., Taylor, W., Barquero, R., López, A., Cerdas, A., \& Murillo, J. (2009b). Geología de la hoja General, Costa Rica. Revista Geológica de América Central, 40, 97-107.

Anchukaitis, K. J., \& Horn S. P. (2005). A 2000-year reconstruction of forest disturbance from southern Pacific Costa Rica. Palaeogeography, Palaeoclimatology, Palaeoecology, 221, 35-54. doi: 10.1016/j.palaeo.2005.02.003

Bold, H. C., \& Wynne, M. J. (1985). Introduction to the Algae: Structure and Reproduction. $2^{\text {nd }}$ ed. Englewood Cliffs, New Jersey: Prentice-Hall.

Clement, R. M., \& Horn S. P. (2001). Pre-Columbian land-use history in Costa Rica: a 3000-year record of forest clearance, agriculture and fires from Laguna Zoncho. The Holocene, 11, 419-426. doi:10.1191/095968301678302850.

Colinvaux, P., De Oliveira, P. E., \& Patiño, J. E. M. (1999). Amazon Pollen Manual and Atlas. Amsterdam: Harwood Academic Publishers.

Córdoba Muñoz, R.; Romero Araya, J. C.; \& Windevoxhel Lora, N. J. (1998). Los Humedales de Costa Rica. San José, Costa Rica: UICN, ORMA. Retrieved from https://portals.iucn. org/library/node/7450

Dean, W. E. (1974). Determination of carbonate and organic-matter in calcareous sediments and sedimentary-rocks by loss on ignition: comparison with other methods. Journal of Sedimentary Petrology, 44, 242-248.

Dillard, G. E. (1999). Common Freshwater Algae of the United States. Berlin, Germany: Cramer.

Haberyan, K. A., Umaña V., G., Collado, C., \& Horn, S. P. (1995). Observations on the plankton of some Costa Rican lakes. Hydrobiologia, 312, 75-85. doi: 10.1007/BF00020763

Haberyan, K. A., Horn, S. P., \& Umaña V. G. (2003). Basic limnology of fifty-one lakes in Costa Rica. Revista de Biología Tropical, 51, 107-122.

Harden, C. (1992). Incorporating roads and footpaths in watershed-scale hydrologic and soil erosion models. Physical Geography, 13, 368-385.

Horn, S. P., \& Haberyan, K. A. (1993). Physical and chemical properties of Costa Rican lakes. National Geographic Research \& Exploration, 9(1), 86-103.

Horn, S. P., \& Haberyan, K. A. (2016). Lakes of Costa Rica. In: M. Kappelle (ed.). Costa Rican Ecosystems. (pp. 656-682). Chicago, Illinois: The University of Chicago Press. doi: 10.7208/chicago/9780226121642.003.0019

Krammer, K., \& Lange-Bertalot, H. (1991). Bacillariophyceae. Süßwasserflora von Mitteleuropa 2. Stuttgart, Germany: Fisher. 
Obando, L. G., \& Kussmaul, S. (2009a). Geología de la hoja Buenos Aires, Costa Rica. Revista Geológica de América Central, 41, 123-136. doi: 10.15517/rgac.v0i41.4184

Obando, L. G., \& Kussmaul, S. (2009b). Mapa geológico de la hoja Buenos Aires. Serie Colección de mapas geológicos (12). Revista Geológica de América Central, 41.

Orvis, K. H., \& Horn, S. P. (2000) Quaternary glaciers and climate on Cerro Chirripó, Costa Rica. Quaternary Research, 54, 24-37. doi: 10.1006/qres.2000.2142

PREPAC. (2005). Inventario Nacional de Cuerpos de Aguas Continentales de Costa Rica. San José, Costa Rica: Plan Regional de Pesca y Acuacultura Continental, OSPESCA/ Taiwán/OIRSA, INCOPESCA.

Reimer, P. J., Bard, E, Bayliss, A, Beck, J. W., Blackwell, P. G., Ramsey, C. B., .., \& van der Plicht, J (2013). Intcal13 and Marine13 radiocarbon age calibration curves $0-50,000$ years cal BP. Radiocarbon, 55, 1869-1887. doi: 10.2458/ azu_js_rc.55.16947

Rodgers III, J. C., \& Horn, S. P. (1996). Modern pollen spectra from Costa Rica. Palaeogeography, Palaeoclimatology, Palaeoecology, 124(1-2), 53-71. doi: 10.1016/0031-0182(96)00004-1

Shuman, B. (2003). Controls on loss-on-ignition variation in cores from two shallow lakes in the northeastern United States. Journal of Paleolimnology, 30, 371-385. doi: 10.1023/B:JOPL.0000007226.68831.e3

Sitchler, J. C., Fisher, D. M., Gardner, T., \& Protti, M. (2007). Constraints on inner forearc deformation from balanced cross sections, Fila Costeña thrust belt, Costa Rica. Tectonics, 26, TC6012. doi:10.1029/2006TC001949

Stone, D. Z. (1962). The Talamanca Tribes of Costa Rica. Papers of the Peabody Museum 43, 1-118.
Stuiver, M., \& Reimer, P. (1993). Extended C-14 database and revised CALIB 3.0 C-14 age calibration program. Radiocarbon, 35, 215-230. doi: 10.1017/S0033822200013904

Sukhanova, I. N. (1978). Settling without the inverted microscope. In: A. Sournia (ed.). Phytoplankton Manual (p. 97). Paris: United Nations Educational, Scientific and Cultural Organization.

Taylor, Z. P., Horn, S. P., \& Finkelstein, D. B. (2015) Assessing intra-basin spatial variability in geochemical and isotopic signatures in the sediments of a small neotropical lake. Journal of Paleolimnology, 54(4). doi:10.1007/ s10933-015-9859-x

Thompson, R. H. (1959). Algae. In: W.T. Edmondson (ed.). Freshwater Biology. (pp. 587-656). New York: Wiley.

Tosi, J. A. (1969). Mapa Ecológico de Costa Rica. San José, Costa Rica:Tropical Science Center.

Umaña V. G., Haberyan, K. A., \& Horn, S. P. (1999). Limnology in Costa Rica. Limnology in Developing Countries, 2, 33-62.

Umaña V. G. (2010). Temporal variation of phytoplankton in a small tropical crater lake, Costa Rica. Revista de Biología Tropical, 58(4), 1405-1419.

Umaña V. G. (2014). Phytoplankton variability in Lake Fraijanes, Costa Rica, in response to local weather variation. Revista de Biología Tropical, 62(2), 483-494.

Umaña V. G. (2016). One year weekly dynamics of limnological conditions and phytoplankton in Lake Bonilla, Costa Rica. Revista de Biología Tropical, 64(4), 1771-1781.

Wallin, T. R., \& Harden, C. P. (1996). Estimating trail-related soil erosion in the humid tropics: Jatun Sacha, Ecuador, and La Selva, Costa Rica. Ambio, 25(8), 517-522. 